\title{
Microorganisms Associated with Deterioration of Stored Banana Fruits
}

\author{
Oye wole O. A. \\ Department of Microbiology, Federal University of Technology, PMB 65, Minna, Niger State, Nigeria
}

\begin{abstract}
Microorganis ms associated with deterioration of banana fruits (Musa sapientum and Musa acuminata var. dwarf Cavendish) were isolated. Rhizoctonia solani was isolated from the M. acuminata var dwarf Cavendish while Aspergillus niger was isolated from M. sapientum. Bacteria isolated were Streptococcus pyogenes and Proteus vulgaris (from M. acuminata var. dwarf Cavendish) and Alcaligenes faecalis and Streptococcus faecalis were isolated from $M$. sapientum. The mean proximate composition of $M$. sapientum on the fifth day of storage gave a decrease in the carbohydrate (18.807 to $5.334 \%$ ) and lipid (3.475 to $2.852 \%)$ contents while an increase was observed in the moisture ( 73.919 to $85.425 \%$ ), protein ( 1.375 to $1.554 \%$ ) and ash (1.008 to $2.431 \%$ ) contents. The mean proximate composition of Musa acuminata var. dwarf Cavendish on the fifth day of storage gave a decrease in the carbohydrate (16.919 to 8.334\%) and lipid (3.292 to $2.874 \%$ ) contents while an increase was observed in the mo isture ( 75.493 to $81.987 \%)$ ), protein (1.713 to $1.947 \%)$ and ash (1.937 to $1.969 \%)$ contents. The fruits were stored in different ways. The results obtained showed that fruits stored at $4 \mathrm{oC} \pm 1$ (in a refrigerator) gave a longer time before in itiation of ripening (20 days) compared with fruit stored in moist sawdust (7 days) and fruits stored in polythene bag moistened with KMn04 solution ( 3 days). The rate of deterioration of the fruits was also examined. Fruits stored in moist sawdust gave no sign of deterioration throughout the course of storage (31 days). Fruits stored at $4 \mathrm{oC} \pm 1$ were contaminated with mold on the 10 th day. Fruits stored in polythene bag moistened with KMn04 solution became contaminated on the 7th day and the control, 8th day. The results of this work show that refrigeration $(4 \mathrm{o} \pm 1)$ appeared to be the most appropriate condition for pro longing the initiation of ripening of banana varieties used while mo ist sawdust appeared to be most suitable for improving the shelf life of the banana fruits.
\end{abstract}

Keywords Deterioration, Proximate Analysis, Ripening, Storage, Contamination, Shelf Life

\section{Introduction}

Banana (Musa species) is a major staple crop of considerable importance in the developing world. They are consumed as an energy giving food and as dessert[1]. Unlike most plantain, banana is usually eaten without further preparation[2].

The colour of banana, cooking banana and plantain probably contributes more to the assessment of quality by the consumer than any other single factor. The colour of the fruit could give an indication of state of deterioration, disease infestation and/or contamination. The market quality and consumer acceptability of banana, cooking banana and plantain are significantly influenced by the colour of the fruit[1]. The peel colour is often the major post-harvest criterion used by researchers, growers and consumers to determine whether the fruit is ripe or

* Corresponding author:

oyewolefemi@gmail.com (Oyewole O.A.)

Published online at http://journal.sapub.org/fs

Copyright (C) 2012 Scientific \& Academic Publishing. All Rights Reserved unripe[3]. In some countries, (e.g. Ghana, Nigeria, Honduras, etc),consumers have developed distinct correlations between colour and the overall quality of specific products[1].

Cooking banana or plantain should be green or yellow, anything which falls short of that (e.g. red plantain) would be difficult to sell[1]. Hence, colour is critical as the first visual assessment of the quality of cooking banana or plantain. Consumers associate the colour of the peel with specific tastes or uses and they will usually buy cooking banana or plantain if the colour is suited to the required purpose or desire[1]. Once harvested, the fruits ripen quickly and have a very short shelf life[4]. Traditionally, the stage of ripening of banana, cooking banana and plantain have been closely linked with the changes in peel colour and the matching of the peel colour against a set of standard colour plates is a common method used to assess the ripeness of the fruit[1]. During ripening of banana, cooking banana and plantain, there is a tremendous increase in the amount of ethylene produced. This increase is usually accompanied by an increase in respiration rate of the fruit (a phenomenon which is called the climacteric). 
The rate of respiration and ethylene production usually depends on storage temperature, age of fruit and cultivar/hybrid[5].

In the trade, seven ripening stages of bananas are generally recognized: stage 1: green; Stage 2: green, traces of yellow; stage 3: more green than yellow; stage 4: more yellow than green; stage 5: green tip and yellow; stage 6: all yellow, and stage 7: yellow, flecked with brown[6]. Beyond the full yellow stage, degenerative changes occur on the skin with the appearance of brown flecks which ultimately coalesce until the skin is blotchy brown[2]. The loss of green colour is due to degradation of the chlorophyll structure[1].

Banana fruits can be contaminated by microorganisms through skin penetration, natural opening or mechanical damage. Microbial spoilage of fruits may be due to bacteria or fungi causing the fruits to be undesirable, reducing the market value and may also cause some side effects such as gastroenteritis, when consumed[7],[8]. Post-harvest diseases can cause serious losses of fruits both in terms of quantity and quality. Fruits microorganisms have no market value.

The storage life of banana fruits can be improved using low temperature, $90 \%$ humidity, removal of ethylene, storing in $5 \% \mathrm{CO}_{2}$ and $3 \%$ oxygen at $28^{\circ} \mathrm{C}$, use of chemicals and irradiation[9], use of packaging materials and fruit processing[10].

The objectives of this study are to isolate mic roorganisms associated with deterioration of banana fruits in storage and to assess common ways that have used to improve the shelf life of the fruits.

\section{Materials and Methods}

\section{Collection of Samples}

Fresh, ripe and green samples of banana fruits $(M$. sapientum and M. acuminata var. dwarf Cavendish) were obtained from the retailer's outlet in Akure, Ondo State, Nigeria. The fruits were collected in a polythene bag and transferred into the laboratory of the Department of Biology, Federal University of Technology, Akure, Nigeria.

\section{Identification of $\mathrm{S}$ poilage Types}

The fresh fruits were placed on sterile glass support in sterile desiccators. The spoilage types were identified by physical examination of the samples. The color changes and mold appearance were observed and recorded.

\section{Preparation of Media}

Media used for the work were nutrient agar, and potatoes dextrose agar for the isolation of bacteria and fungi respectively. The media were prepared using manufacturer's instruction and sterilized using autoclave at $121^{\circ} \mathrm{C}$ for fifteen minutes.

\section{Determination of Proximate Analysis}

The proximate analysis of the banana fruits was carried out on the fresh fruits and fruits stored for five days. The percentage proximate content carried out include: moisture, carbohydrate, ash, crude protein, crude fibre and lipid using methods described by Peas on[11].

\section{Isolation and Characterization of Microorganisms}

Streak plate method was used for the isolation of bacteria while a portion of the fruit was aseptically inoculated onto the centre of potatoes dextrose agar for the isolation of fungi. The microorganisms were subcultured into freshly prepared media for pure culture isolation. The bacteria were characterized using methods described by Cowan[12] while the fungi were identified using cultural and microscopic examination as described by Domsch and Gams[13].

\section{Pathogenicity Test}

Healthy, fresh and unripe fruits were each inoculated with isolates in order to establish the spoilage symptoms of each isolate. The fruits were surface disinfected using cotton wool mo istened with ethanol. Each isolate was inoculated into $9 \mathrm{mls}$ of sterile water using inoculating loop and needle for bacteria and fungi respectively. One milliliter $(1 \mathrm{ml})$ of the inoculum was inoculated into each fruit using a sterile syringe.

The Effects of Different Storage Conditions on the rate of ripening banana fruits

Unripe, matured banana fruits were stored using refrigerator $\left(4^{\circ} \mathrm{C} \pm 1\right)$, polythene bag moistened with $\mathrm{KMn} 0_{4}$ solution, and moist sawdust to examine the rate of ripening of the fruits. A control was also setup at ambient temperature in a storage cabinet. Ripeness was currently assessed visually by comparing the color of the peel to standardized color charts that describe the seven ripening stages[6]. The ripening progression of the fruits were scored using number 1 for green, 2 for traces of yellow, 3 for more green than yellow, 4 for more yellow than green, 5 for full yellow, 6 for yellow with traces of brown and 7 for more brown than yellow.

\section{Determination of Rate of Deterioration under Different} Storage Conditions

Unripe, matured banana fruits were stored using refrigerator $\left(4^{\circ} \mathrm{C} \pm 1\right)$, polythene bag moistened with $\mathrm{KMnO}_{4}$ solution, and moist sawdust to examine the rate of deterioration of the fruits. A control was also setup at ambient temperature in a storage cabinet. The observed deterioration progression of the fruits were scored using number 1 for green, 2 for traces of yellow, 3 for more green than yellow, 4 for more yellow than green, 5 whit ish tip with for full yellow colour, 6 for yellow with traces of brown and 7 for more brown than yellow, 8 for all brown flecks with soft flesh.

\section{Results}

Mean Proximate Composition of $M$. sapientum and $M$. acuminata var dwarf Cavendish 
Table 1. Mean Proximate Composition of M. sapientum and M. acuminata var dwarf Cavendish

\begin{tabular}{|c|c|c|c|c|}
\hline & \multicolumn{2}{|c|}{ M. sapientum } & \multicolumn{2}{c|}{ M. acuminata var dwarf cavendish } \\
\hline Parameters & Fresh & 5days of storage & Fresh & 5 days of storage \\
\hline \% Moisture & 73.919 & 85.425 & 75.493 & 81.987 \\
\hline \% protein & 1.375 & 1.554 & 1.713 & 1.947 \\
\hline \% carbohydrate & 18.807 & 5.334 & 16.917 & 8.334 \\
\hline \% crude fiber & 1.416 & 2.454 & 1.702 & 2.889 \\
\hline \% lipid & 3.475 & 2.852 & 3.292 & 2.874 \\
\hline \% ash & 1.008 & 2.431 & 1.937 & 1.969 \\
\hline
\end{tabular}

Table 2. Microorganisms isolated and their spoilage symptoms

\begin{tabular}{|c|c|}
\hline M. sapientum & M. acuminata var. dwarf Cavendish \\
\hline Aspergillus niger (black moldy spot) & Rhizoctonia solani (white moldy spot) \\
\hline Strept.pyogenes (brown rot) & Strept.pyogenes (brown rot) \\
\hline Alcaligenes faecalis (brown rot) & Proteus vulgaris (brown rot) \\
\hline
\end{tabular}

Table 1 shows the proximate composition of fresh $M$. sapientum and M. acuminata var dwarf Cavendish. There was an increase in the percentage (\%) mo isture contents (from 73.919 to 85.425), protein contents (from 1.375 to 1.554), crude fibre contents (from 1.416 to 2.454) and ash contents (from 1.008 to 2.431) between the fresh fruits and fruits at five days of storage while there was a decrease in the percentage (\%) carbohydrate contents (from 18.807 to 5.334) and lipid contents (from 3.475 to 2.852).

At 5 days of storage, M. acuminata var. dwarf Cavendish recorded an increase in the percentage (\%) moisture contents (from 75.493 to 81.987 ), protein contents (from 1.713 to 1.947), crude fibre contents (from 1.702 to 2.889 ) and ash contents (from 1.937 to 1.969 ) between the fresh fruits and fruits stored at five days of storage while there was a decrease in the percentage (\%) carbohydrate contents (from 16.917 to 8.334 ) and lipid contents (from 3.292 to 2.874).

Micr oorg anis ms isolated and their s poilage symptoms

Table 2 shows microorganis ms isolated from the banana fruits and their spoilage symptoms. Fungi isolated from $M$. sapientum was Aspergillus niger with a characteristic black moldy spot while bacteria isolated were Strepococcus pyogenes with a characteristic brown rot and Alcaligenes facalis with brown rot symptom.

Fungus isolated from M. sapientum was Rhizoctonia solani with a characteristic white moldy spot while bacteria isolated include Streptococcus pyogenes with a characteristic brown rot and Proteus vulgaris with brown rot symptom.

\section{Colour ratings of $M$ sapientum stored under different} storage conditions

Figure 1 shows the colour ratings of M. sapientum stored under refrigeration temperature $\left(4^{\circ} \mathrm{C} \pm 1\right)$, polythene bags mo istened with $\mathrm{KMn} 04$ solution and moist sawdust for thirty (30) days. The control (fruits stored under ambient temperature of $28^{\circ} \mathrm{C} \pm 2$ ) had the least day (14days) before attaining the last stage of colour rating (stage 7), fo llowed by fruits stored in polythene bags moistened with $\mathrm{KMn} 04$ solution and fruits embedded in sawdust (18days) while fruits stored in refrigeration temperature $4^{\circ} \mathrm{C} \pm 1$ took 28days before reaching the last stage of colour ratings chart (stage 7).

Colour ratings of $M$. acuminata var. dwarf Cavendish store $d$ under different storage condi tions

Figure 2 shows the colour ratings of M. acuminata var. dwarf Cavendish stored under refrigeration temperature $\left(4^{\circ} \mathrm{C} \pm 1\right)$, polythene bags moistened with $\mathrm{KMn}_{4}$ solution and mo ist sawdust for thirty (30) days. The control (fruits stored under ambient temperature of $28^{\circ} \mathrm{C} \pm 2$ ) had the least day (12.5days) before attaining the last stage of colour rating (stage 7), followed by fruits stored in polythene bags mo istened with $\mathrm{KMnO}_{4}$ solution and fruits embedded in sawdust (15days) while fruits stored in refrigeration temperature $4^{\circ} \mathrm{C} \pm 1$ took 26days before reaching the last stage of colour ratings chart (stage 7).

\section{Deterioration of $M$. sapientum stored under different storage conditions}

Figure 3 shows the deterioration of $M$. sapientum stored under refrigeration temperature $\left(4^{\circ} \mathrm{C} \pm 1\right)$, polythene bags mo istened with $\mathrm{KMnO}_{4}$ and mo ist sawdust for thirty (30) days. Fruits stored in polythene bag moistened with $\mathrm{KMn} 0_{4}$ was the first to deteriorated (13 days of storage), followed by the control (17days of storage) and refrigeration temperature $\left(4^{\circ} \mathrm{C} \pm 1\right)$ (28days). Fruits embedded in mo ist sawdust was not deteriorated throughout the storage period of 30days.

Deterioration of $M$. acuminata var. dwarf Cavendish store d under different storage condi tions

Figure 4 shows the deterioration of $M$. acuminata var. $d$ warf Cavendish stored under refrigeration temperature $\left(4^{\circ} \mathrm{C} \pm 1\right)$, polythene bags moistened with $\mathrm{KMnO}_{4}$ and mo ist sawdust for thirty (30) days. Fruits stored in polythene bag mo istened with $\mathrm{KMn}_{4}$ was the first to deteriorated (13 days of storage), followed by the control (16days of storage) and refrigeration temperature $\left(4^{\circ} \mathrm{C} \pm 1\right)$ (30days). Fruits embedded in moist sawdust was not deteriorated throughout the storage period of 30days. 


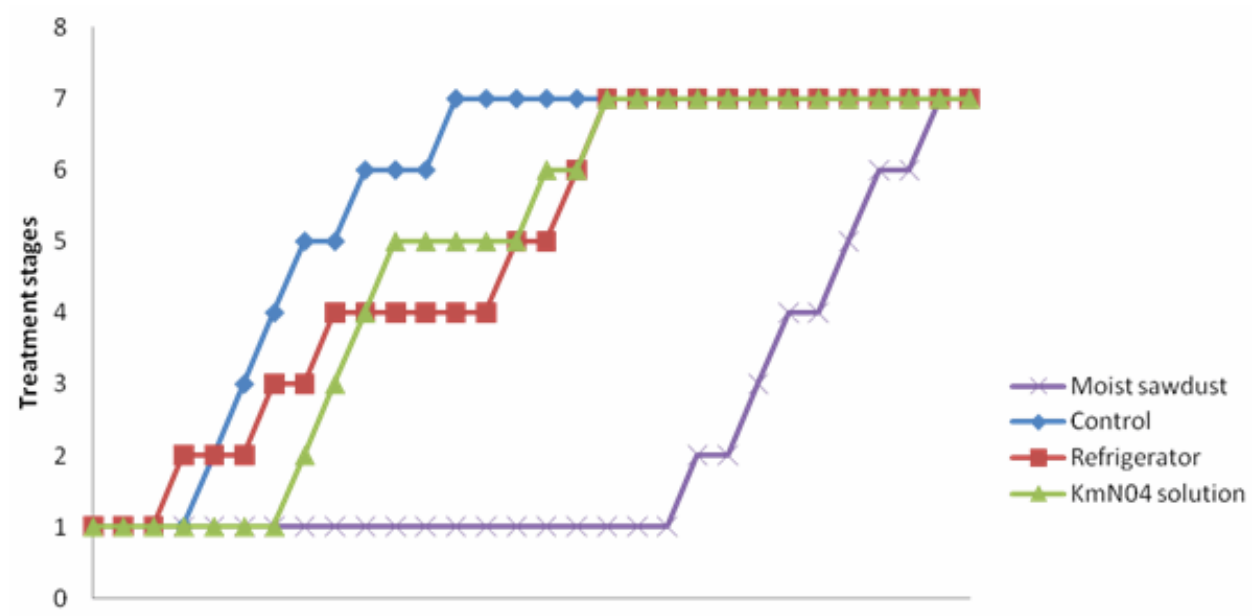

1223445667889101112131415161718192021222324252627282930

Figure 1. Colour ratings of M. sapientum stored under different conditions

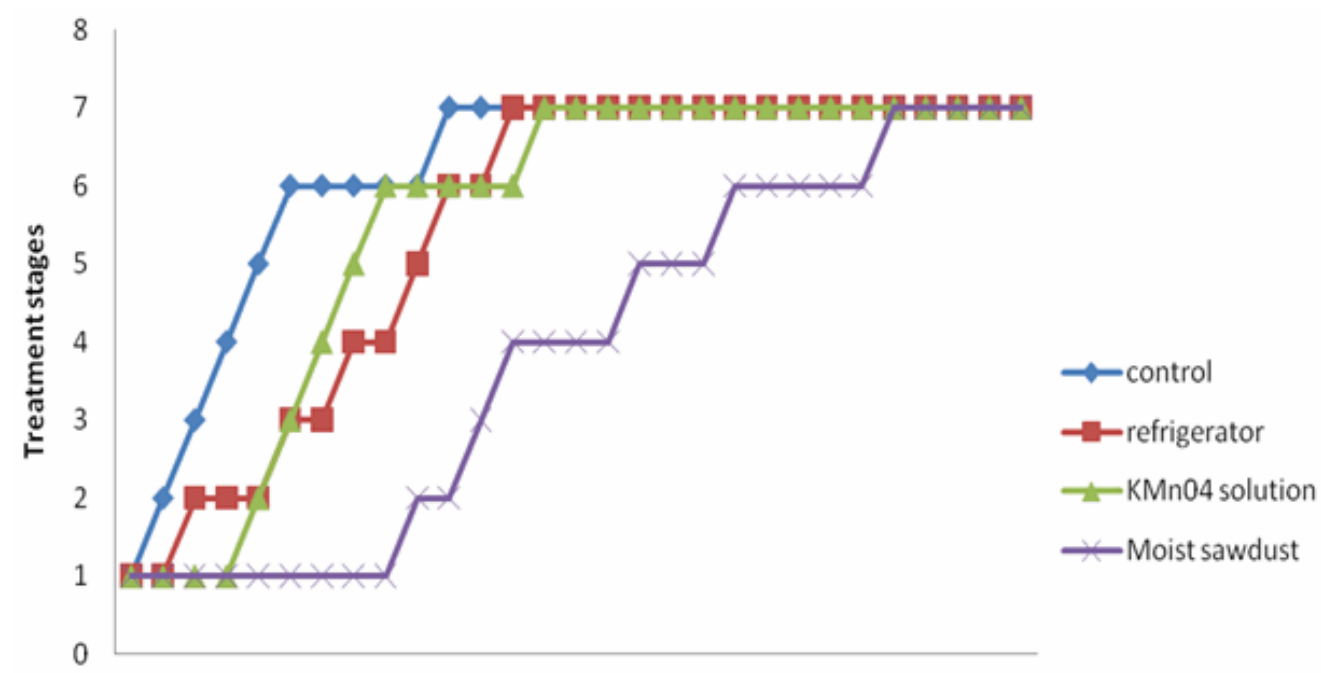

12334567891011121314151617181920212223242526272829

Figure 2. Colour ratings of M. acuminata var dwarf cavendish under different storage conditions

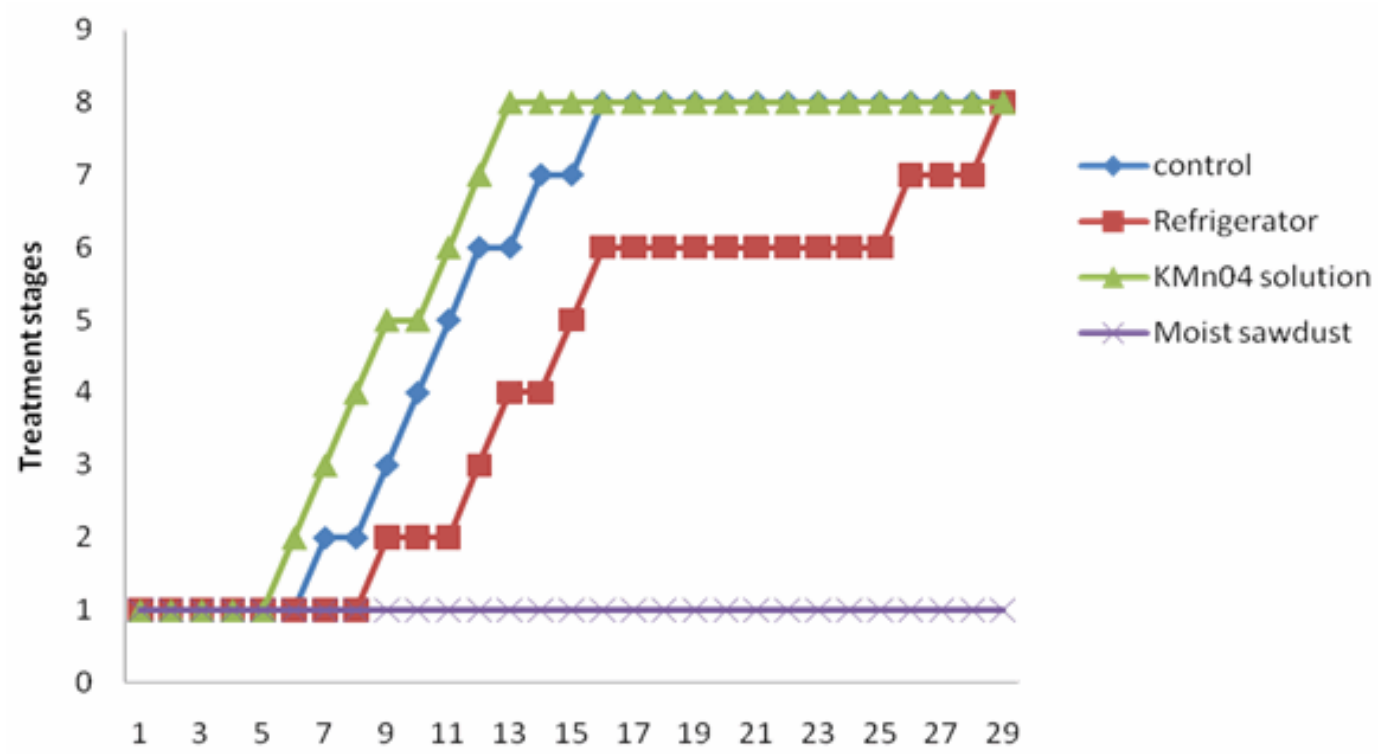

Figure 3. Deterioration of $M$. sapientum at different storage conditions 


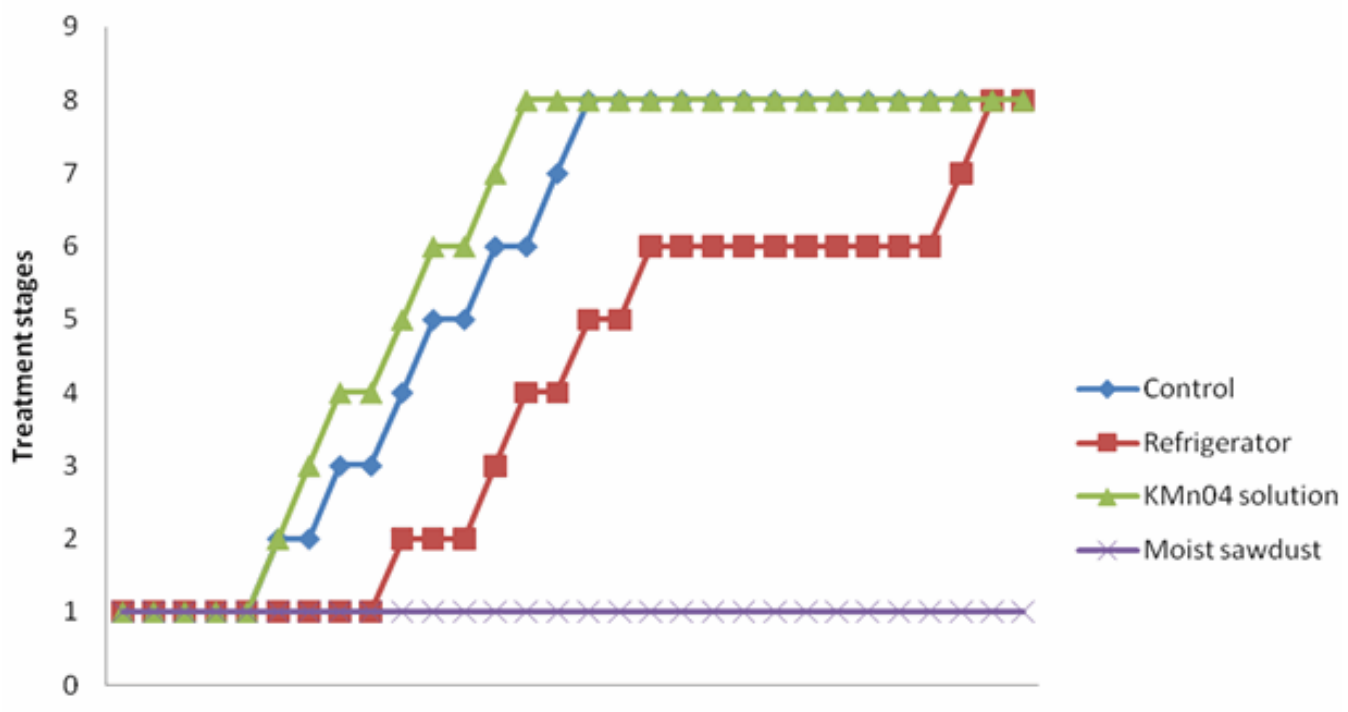

123456789101112131415161718192021222324252627282930

Figure 4. Deterioration od M. acuminata var dwarf cavendish at different storage condition

\section{Discussion}

Two fungi $A$. niger and $R$. solani were isolated from $M$. sapientum and M. acuminata var. dwarf Cavendish and respectively (Table 3). Hansen et al.[14] reported the occurrence of $R$. solani in banana ground parts and above ground. The ability of these fungi to hydrolyse the sugar in the banana fruits may be due to the present of intracellular hydrolyzing enzymes. Bacteria isolated include Streptococcus pyogenes, Proteus vulgaris and Alcaligenes faecalis (Table 3). Their presence may be as secondary pathogen.

An increase in the moisture contents of the fruits on the 5th day (Tables 1) correspond with reports of [2] who stated that degenerative changes occurring banana deterioration including increasing watery and non-acceptability of fruits. A decrease in the percentage carbohydrate and fats composition may be due to their utilization by the microorganisms. Al-Zaemey et al.[17] reported that microorganis ms cause undesirable changes and reduction in nutrient and market values of banana fruits. Refrigeration temperature $\left(4^{\circ} \mathrm{C} \pm 1\right)$ had the longest time period before initiation of ripening compared with control, fruits stored in polythene bag moistened with $\mathrm{KMnO}_{4}$ solution and fruits embedded in moist sawdust (Fig. 1 and 2). This is in line with reports of [10] and [9] who stated that with refrigerator, ripening took a longer period, reducing the environmental temperature, reduces the rate of respiration thereby delaying ripening.

Fruits embedded in moist sawdust showed no mold appearance throughout the course of storage (30 days), compared with fruits stored in refrigerator and polythene bag mo istened with $\mathrm{KMnO}_{4}$ solution and control (no treatment) (Fig. 3 and 4).

\section{Conclusions}

The results of this study showed that refrigeration temperature $\left(4^{\circ} \mathrm{C} \pm 1\right)$ appeared to be the most suitable condition for prolonging the ripening of banana fruits and embedding banana fruits in moist sawdust appeared to be the best condition for imp roving the shelf life of banana fruits.

\section{REFERENCES}

[1] Dadzie, B.K., Orchard, J.E. (1997). Routine Post Harvest Screening of Baacuminata/Plantain Hybrids: Criteria and Methods. INIBAP Technical Guidelines 2. International Plant Genetic Resources Institute, Rome, Italy; International Network for the Improvement of Banana and Plantain, Montpellier, France; ACP-EU Technical Centre for Agricultural and Rural Cooperation, Wageningen, The Netherlands.

[2] Falana, I.B. (1997). Effects of low irradiation doses and some physical treatment on the keeping of plantain (Musa AAB). Thesis submitted for the requirement of $\mathrm{PhD}$ award in Food Science and Technology, OAU, Ile-Ife pp. 8-26, 83-84

[3] Medlicott, A. P., Semple, A. J., Thompson, A. J., Blackbourne, H. R., Thompson, A. K. (1992). Measurement of colour changes in ripening bananas and mangoes by instrumental, chemical and visual assessments. Trop. Agric. 69(2):161-166.

[4] Olorunda, A.O., Aworh, O.C. (1994). Effects of Tal-prolong, a surface coating agent on the shelf life and quality attributes of plantain. Journal of Food Science and Agriculture 35, pp. 573-578.

[5] Kader, A. A. (1987). Respiration and gas exchange of vegetables. In Post-harvest physiology of vegetables. (J. Weichmann, ed.). Marcel Dekker Inc., New York, Pp. 27-30

[6] Li, M., Slaughter, D.C., Thompson, J.E. (1997). Optical chlorophyll sensing system for banana ripening. Postharvest Biol. Technol., 12(3): 273-283. 
[7] Al- Zaemey, A.B.S., Falana, I.B., Thomp son, A.K. (1989). Effects of permeable fruit coating on the storage life of plantain and banana. Aspects of Applied biology, 20: 74 .

[8] Prescott, L. M., John, P.H., Donald, A.K. (2002). Microbiology, 4th edition. NY McGraw Publishers pp. 11-14.

[9] Shaun, R., Ferris, B. (1997). Improving storage life of plantain and banana, IITA Research Guide, 61 pp. 21

[10] Robinson, J.C. (1996). Banana and plantain, Journal of Crop Production Science in Horticulture 5 CAB International UK pp. 55-178.
[11] Peason, D. (1975). The chemical analysis of food. The 7th edition. Chemical publishers Co, Inc. NY pp. 95-105.

[12] Cowan, S.T. (1974). Manual for the identification of medical Bacteria 2nd ed. Cambridge University Press New York

[13] Domsch, K.H., Gams, W. (1970). Fungi in Agricultural Soils. Longman Group Limited, London, pp. 20-152.

[14] Hansen, L.E., Panella, L., Hill, H. L., Preston, G.M. (2003). Screening Biological control agents for Rhizoctonia solani control in sugar beets pp 1-5. 